Research Article

\title{
Combined Application of Phosphorus Fertilizer with Tithonia Biomass Improves Grain Yield and Agronomic Phosphorus Use Efficiency of Hybrid Maize
}

\author{
Solomon Endris \\ Ethiopian Institute of Agricultural Research, P. O. Box 2003, Addis Ababa, Ethiopia \\ Correspondence should be addressed to Solomon Endris; solomon5994@gmail.com
}

Received 8 April 2019; Accepted 4 June 2019; Published 1 July 2019

Academic Editor: Maria Serrano

Copyright ( 2019 Solomon Endris. This is an open access article distributed under the Creative Commons Attribution License, which permits unrestricted use, distribution, and reproduction in any medium, provided the original work is properly cited.

\begin{abstract}
Low soil phosphorous level is among several constraints limiting crop productivity in southwestern Ethiopia. The dominant soil types in the region are acidic nitosols that are low in plant-available phosphorus. Most farmers cultivate maize with minimal external inputs and hence result in suboptimal yield levels. The effect of applying Tithonia biomass and phosphorus fertilizer on the agronomic efficiency of phosphorus and yield of maize was therefore investigated in a randomized complete block design with three replications. Tithonia (Tithonia diversifolia) biomass and Triple Superphosphate (TSP) were used as organic and inorganic sources of phosphorus, respectively. Significant treatment differences $(P<0.01)$ were observed for most of the parameters studied including agronomic efficiency, partial factor productivity (PFP), and grain yield. Agronomic phosphorus use efficiency increased from 26.3 at the sole TSP to 163 at treatment 7, a staggering 520\% increment when combined with Tithonia biomass. Similarly, PFP of phosphorus increased from 169.1 to 324.8. At the same time, 53\% increment of the grain yield was recorded over the control. Although applying the highest Tithonia biomass alone gave the highest grain yield, application of just $50 \%$ of the highest rate of Tithonia biomass and TSP looks more appealing to smallholder maize producers in the region. The result therefore indicated that Tithonia biomass could be utilized in smallholder maize production system as a source of plant nutrients such as phosphorus; it also emphasized the need to allot more resources and attention in exploring locally available and cheap sources of plant nutrients which could augment crop productivity amid the mounting financial challenges faced by farmers in the region.
\end{abstract}

\section{Introduction}

Maize is a staple food crop in the southwestern part of Ethiopia, a region characterized by adequate rainfall and moderate temperature. However, the crop yield is often limited due to a combination of several factors that include continuous monocropping and inadequate fertilizer use, which in turn caused soil fertility degradation. Soil erosion, nutrient imbalances, removal of crop residues, and poor cultural practices are believed to be among the leading factors causing low crop productivity in most parts of the country. Hence, the fertilizer application has become necessary to sustain crop yields, but repeated use of urea and DAP fertilizers, the available fertilizer types in the country until recently, has not been of much help to address the problem. High cost of fertilizers was also implicated in reluctance of farmers to adopt fertilizer recommendations. Therefore, exploring cheaper and easily available alternative sources of plant nutrients could be a wise and sensible idea to improve crop productivity and rural food insecurity.

Although organic resources are often proposed as alternatives to commercial mineral fertilizers, traditional organic materials such as crop residues and animal manure may not be sufficient to reverse soil fertility decline because they are low in nutrients, and their processing and application are labor demanding [1].

The incorporation of perennials into cropping systems via agroforestry can help sustain agricultural production in tropical regions where the use of mineral fertilizers is limited [2]; one such practice is biomass transfer in which plant biomass produced outside the crop-growing area is transferred to crops to provide an input of nutrients. The success 
of the biomass transfer may depend on whether or not the plant accumulates high level of nutrients in its foliage and readily releases the nutrients in plant-available forms upon incorporation to soil. Among such plants that are deemed suitable for the biomass transfer is Tithonia (Tithonia diversifolia). Green biomass of Tithonia has been identified as a useful resource for the biomass transfer [3]. Tithonia has wider ecological adaptation and is available in many countries in East and South Africa from hedges established around farms and households and/or voluntary growth of this shrub along roadsides and in other waste lands [4].

Commonly known as Mexican sunflower (Tithonia diversifolia) is an annual, aggressive leafy weed growing to a height of $3 \mathrm{~m}$ or more and adaptable to most soils $[5,6]$. In southwestern Ethiopia, Tithonia is not as well known and locally available as in other East African countries like Kenya. It is only maintained and multiplied at limited locations in the research centre for research purposes. It was introduced from neighboring Kenya due to the rising interest in its potential use as a source of plant nutrients mainly through the biomass transfer; however, its controlled dissemination in the region is pending investigations on its potential role to supply plant nutrients under prevailing conditions of the region. The abundance and adaptability of Tithonia to various environments coupled with its rapid growth, very high vegetative matter turn over, and near nil investment cost on its production makes it a suitable candidate for soil regeneration among smallholder farmers [7].

Concentrations of nitrogen $(\mathrm{N})$, phosphorus $(\mathrm{P})$, and potassium $(\mathrm{K})$ in the green leaf biomass of Tithonia are relatively high [4], and these nutrients are rapidly released in plant-available forms during decomposition [3, 8]. Data compiled by Palm et al. [1] indicated high content of $\mathrm{N}, \mathrm{P}$, and $\mathrm{K}$ in Tithonia biomass corresponding to 36,27 , and $43 \mathrm{~kg} \cdot \mathrm{t}^{-1}$ (dry weight basis). It has also been shown that the $\mathrm{N}$ concentration of Tithonia leaves is higher than the critical level of 2.0 to $2.5 \%$ below which net immobilization of $\mathrm{N}$ would be expected [1], and the P concentration is also higher than the critical level of $0.25 \%$ for net $\mathrm{P}$ mineralization $[1,9]$. Organic matter with the $\mathrm{N}$ content below $3 \%$ needs to be applied in combination with additional mineral nitrogen to substantially increase crop yields [10].

A paradox in promoting the use of Tithonia comes from the fact that Tithonia is a nonleguminous plant; i.e., it does not fix nitrogen. Hence, it does not supply a net input of nitrogen and other nutrients to the farm [4], but it enhances the reutilization of nutrients already in the system [11]. Studies in the highlands of western Kenya identified green biomass of Tithonia as an effective source of nutrients for maize [2]. Research in Malawi [12] and Zimbabwe [13] have similarly reported Tithonia biomass as an effective nutrient source for maize.

However, the quantity of green biomass available from Tithonia growing near smallholder agricultural fields may often be insufficient to supply all the nutrients required. Moreover, the utilization of organic materials as source of phosphorus for crop production is normally limited by their low $\mathrm{P}$ content, hence requiring large quantities of organic materials to meet moderate yield increase [14]. The integration of Tithonia biomass with mineral fertilizers is therefore a crucial strategy to address such problems.

Considering the role of organic residues in reducing soil $\mathrm{P}$ adsorption capacity [15], increasing $\mathrm{pH}$ [16], and increasing soil biological activity [17], it is strongly believed that the combination of organic and inorganic nutrient sources is more beneficial than the sole application of fertilizers. Similar or a larger effect on available $\mathrm{P}$ pools were reported as a result of combining Tithonia diversifolia (Hemsley A. Gray) and TSP at $15 \mathrm{~kg} \cdot \mathrm{P} \cdot \mathrm{ha}^{-1}$ than the sources applied alone or at equal $\mathrm{P}$ rates [8]. The goal of the integrated nutrient management (INM) is to integrate the use of all natural and man-made sources of plant nutrients so that crop productivity increases in an efficient and environmentally benign manner, without sacrificing soil productivity of future generations [18].

Several studies have reported data showing Tithonia as a useful source of nutrients for the production of maize [5-7, 19] and other crops like Brassica oleraceae [20] and okra (Abelmoschus esculentus L.) [21]. However, information on the use of Tithonia for plant nutrient management in Ethiopia is almost nonexistent. Hence, data reported in this paper may shade light and pave the way for more experiments in the region and provide useful information as to whether the plant should be promoted and disseminated among smallholder farmers in southwestern Ethiopia. In addition, the weedy nature of Tithonia entails careful investigations on all aspects relating to the plant before any recommendation is made to disseminate it outside the research centre.

The prevailing high moisture and temperature conditions in southwestern Ethiopia favors the decomposition of Tithonia biomass and release of the nutrients retained therein rapidly. In general, the study was conducted to evaluate the potential use of Tithonia biomass as a source of nutrients for maize through biomass transfer and to determine the best combination of Tithonia biomass and inorganic phosphorus fertilizer which could easily be applied in maize-based cropping systems of the region.

\section{Materials and Methods}

2.1. Study Area. The study was conducted on farm at locations near Jimma town in the Jimma zone, southwestern Ethiopia (Figure 1). The experiments were conducted at two sites (Serbo and Melko) for a duration of two years. The dominant soil type of the area is nitosol with slight acidity. Maize is among the most important field crops cultivated in the area.

2.2. Methodology. Tithonia (Tithonia diversifolia (Hemsley) A. Gray) was intensively multiplied at Jimma Agricultural Research Centre four months ahead of maize sowing in order to get sufficient biomass (foliage) for the experiment. The treatments were Tithonia leaf biomass, urea, and TSP as sources of nitrogen and phosphorus. Tithonia and TSP were applied separately (but at same time) in different proportions to supply $20.3 \mathrm{~kg} \cdot \mathrm{P} \cdot \mathrm{ha}^{-1}$, which is the recommended 


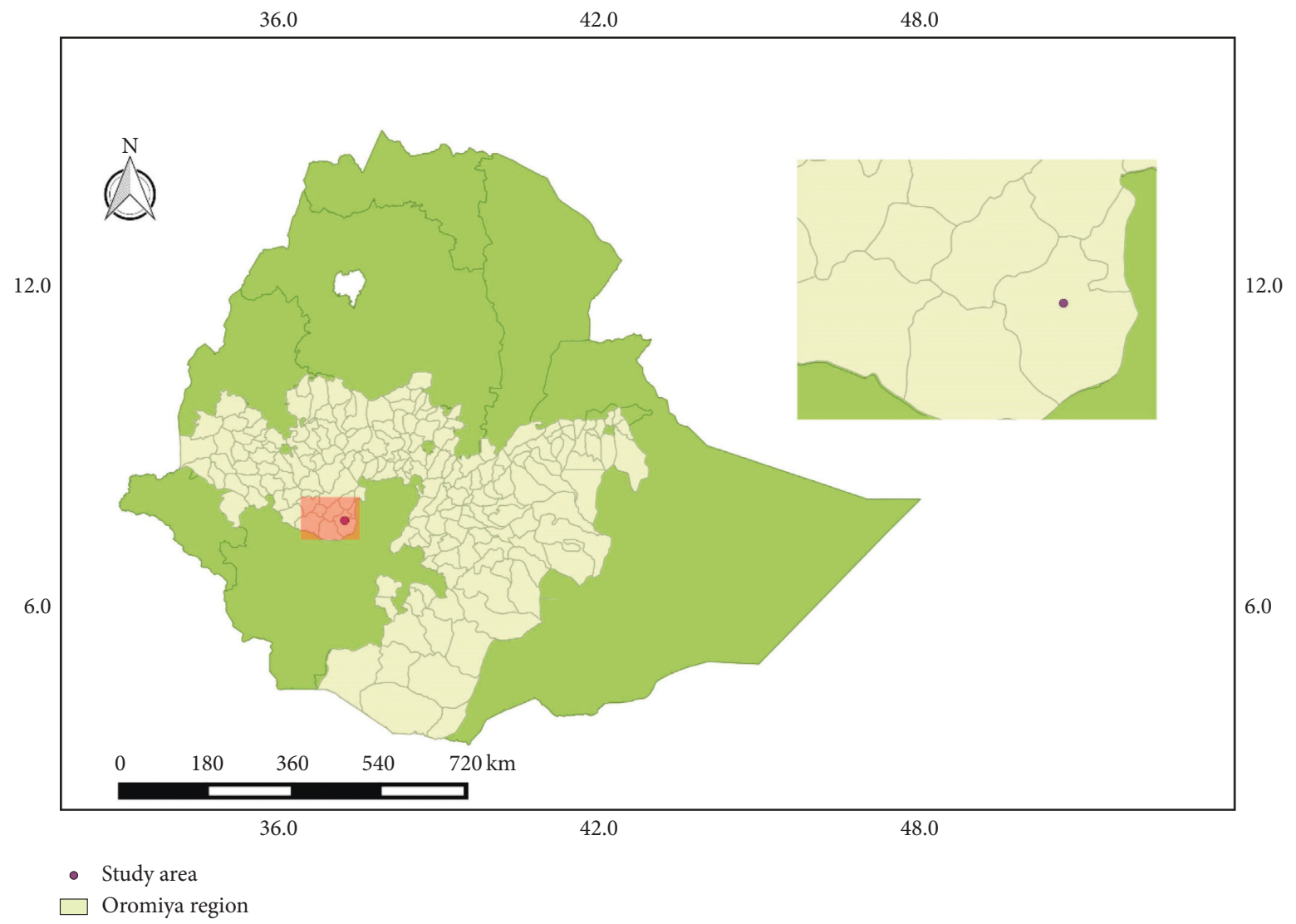

FIgURE 1: Map of Ethiopia showing the study area.

phosphorus fertilizer rate for area. Moreover, known quantity of nitrogen was also indirectly supplied from Tithonia biomass along with each Tithonia treatment added to supply phosphorus (the amount was determined using laboratory analysis). The quantity of N, P, and Tithonia biomass was determined from the concentration of nutrients in Tithonia which was $0.03 \mathrm{~kg} \cdot \mathrm{N}$ and $0.003 \mathrm{~kg} \cdot \mathrm{P}$ (i.e., $3 \% \mathrm{~N}$ and $0.3 \% \mathrm{P}$ ) per kilogram of Tithonia biomass (dry weight basis). Preliminary soil chemical properties for composite samples collected at the start of the study indicated low available soil $\mathrm{P}$ levels and low soil $\mathrm{pH}$ which was in the acidic range (Table1).

The amount of $\mathrm{P}$ supplied from TSP was $\mathbf{0 , 2 . 0 , 4 . 0 , 6 . 1}$, $8.1,10.1,12.0,14.2$, and $20.3 \mathrm{~kg} \cdot \mathrm{P} / \mathrm{ha}$, and the remaining amount of phosphorus was supplied from Tithonia biomass, which required $6767,6100,5433,4733,4067,3400$, 2767, 2033, and $0 \mathrm{~kg} / \mathrm{ha}$ Tithonia biomass to supply 20.3, $14.2,12.0,10.1,8.1,6.1,4.0,2.0$, and $0 \mathrm{~kg} \cdot \mathrm{P} / \mathrm{ha}$, respectively. The treatments were arranged in proportional substitution of the two phosphorus sources (TSP and Tithonia biomass) (Table 2). Hence, the amount of $\mathrm{P}$ supplied from both sources adds up to $20.3 \mathrm{~kg}$ for all treatments except the control.

The treatments were arranged in randomized complete block (RCB) design with three replications using hybrid maize variety $B H 660$ as a test crop. The average nutrient concentration of Tithonia leaves was determined to adjust the amount of biomass added to the required amounts of $\mathrm{N}$ and $\mathrm{P}$ for the experiment. The leafy biomass of Tithonia was
TABLe 1: Soil chemical properties (initial).

\begin{tabular}{lc}
\hline Soil properties & Values \\
\hline $\mathrm{pH}(1: 2.5)$ & 4.29 \\
Available P $(\mathrm{ppm})$ & 1.98 \\
$\%$ TN & 0.15 \\
\% OC & 2.01 \\
\hline
\end{tabular}

chopped and incorporated 3 weeks before sowing. All phosphorus fertilizers (TSP) were applied at sowing, and the nitrogen fertilizer (urea) was applied in split at sowing and at the knee height stage of the crop.

Agronomic phosphorus use efficiency (AE) and partial factor productivity (PFP) were used to assess efficiency of applied phosphorus from the different sources. Hence, agronomic phosphorus use efficiency AEx was calculated as the amount $(\mathrm{kg})$ of grain yield per $\mathrm{kg}$ of applied phosphorus from both sources of phosphorus [22]:

$$
\mathrm{AE}=\frac{\mathrm{YP}-\mathrm{Y} 0}{\mathrm{Fp}},
$$

where $\mathrm{Fp}$ is the amount of $\mathrm{P}$ applied in TSP + Tithonia biomass, $\mathrm{YP}$ is the grain yield at a particular rate of $\mathrm{P}$, and $\mathrm{Y} 0$ is the grain yield under no $\mathrm{P}$ application.

The partial factor productivity (PFP) index was also calculated based on grain yield per unit of nutrient applied in fertilizer: 
TABLE 2: Description of the treatments.

\begin{tabular}{|c|c|c|c|c|c|}
\hline \multirow{2}{*}{ Treatment no. } & \multirow{2}{*}{ Treatments } & \multicolumn{2}{|c|}{ Amount of $\mathrm{P}$ added (kg/ha) } & \multicolumn{2}{|c|}{ Amount of $\mathrm{N}$ added $(\mathrm{kg} / \mathrm{ha})$} \\
\hline & & From Tithonia & From fertilizer & From Tithonia & From fertilizer \\
\hline 1 & Control & 0 & 0 & 0 & 0 \\
\hline 2 & $\mathrm{~N}$ & 0 & 0 & 0 & 69 \\
\hline 3 & $\mathrm{P}$ & 0 & 20.3 & 0 & 0 \\
\hline 4 & $\mathrm{NP}^{*}$ & 0 & 20.3 & 0 & 69 \\
\hline 5 & $70 \% \mathrm{P}(\mathrm{TSP})+30 \% \mathrm{P}(\text { Tithonia })^{* *}$ & 6.1 & 14.2 & 61 & 0 \\
\hline 6 & $60 \% \mathrm{P}(\mathrm{TSP})+40 \% \mathrm{P}($ Tithonia $)$ & 8.3 & 12.0 & 83 & 0 \\
\hline 7 & $50 \% \mathrm{P}(\mathrm{TSP})+50 \% \mathrm{P}$ (Tithonia) & 10.2 & 10.1 & 102 & 0 \\
\hline 8 & $40 \% \mathrm{P}(\mathrm{TSP})+60 \% \mathrm{P}$ (Tithonia) & 12.2 & 8.1 & 122 & 0 \\
\hline 9 & $30 \% \mathrm{P}(\mathrm{TSP})+70 \% \mathrm{P}$ (Tithonia) & 14.2 & 6.1 & 142 & 0 \\
\hline 10 & $20 \% \mathrm{P}(\mathrm{TSP})+80 \% \mathrm{P}$ (Tithonia) & 16.3 & 4.0 & 163 & 0 \\
\hline 11 & $10 \% \mathrm{P}(\mathrm{TSP})+90 \% \mathrm{P}$ (Tithonia) & 18.3 & 2.0 & 183 & 0 \\
\hline 12 & Tithonia alone $(100 \% \mathrm{P})$ & 20.3 & 0 & 203 & 0 \\
\hline
\end{tabular}

${ }^{*}$ Recommend rate for Jimma and the surrounding areas; ${ }^{* *}$ percentages indicate amount of $\mathrm{P}$ derived from the respective sources.

$$
\mathrm{PFP}=\frac{\mathrm{YP}}{\mathrm{Fp}},
$$

where $\mathrm{Fp}$ is the amount of $\mathrm{P}$ applied in TSP + Tithonia biomass and $\mathrm{YP}$ is the grain yield at a particular rate of $\mathrm{P}$.

2.3. Statistical Analysis. Analysis of variance (ANOVA) was used to test variations between treatments, and mean comparisons were also made where appropriate using Tukey's HSD and Fisher's LSD method. The Statistical software Minitab 17.3.1 (Minitab, Inc.) and XLSTAT 2018 [23] were employed for data analysis and graphics reported in this study.

\section{Results}

3.1. Agronomic $P$ Use Efficiency and Partial Factor Productivity. The combined application of TSP and Tithonia biomass as the phosphorus source for maize production significantly improved agronomic efficiency of applied phosphorus $(P<0.05)$ (Table 3$)$. The combined treatments had significantly higher agronomic phosphorus use efficiency $\left(\mathrm{AE}_{P}\right)$ than the sole application of TSP (Table 3 and Figure 2).

Data obtained in the first year at Serbo indicated that treatment 7 , where $50 \%$ of each source (Tithonia and TSP) combined to supply the required amount of phosphorus, had $30 \%$ higher $\mathrm{AE}_{P}$ than the recommended $\mathrm{N}$ and $\mathrm{P}$ from urea and TSP (Table 3). The treatment with Tithonia biomass alone supplying the recommended amount of $\mathrm{P}$ (i.e., treatment 12) had the highest $\mathrm{AE}_{P}$, which was $88.6 \%$ higher than treatment 4 (Table 3 ). However, considering the bulk of Tithonia biomass required to supply the recommended rate of $\mathrm{P}$ for maize and the nonsignificant yield difference between the treatments (treatment 12 and 7), treatment 7 would serve the intended purpose of integrated nutrient management in smallholder maize production settings of the region.

Similarly, data collected at Serbo during the second year indicated that treatment 7 had $113.6 \%$ higher $\mathrm{AE}_{P}$ than treatment 4 (Table 3 ). The highest $\mathrm{AE}_{P}$ was recorded for treatment 12, but the difference with treatment 7 was not significant at $5 \%$ level of probability $(P=0.05)$. In addition, due to the same justification given above, treatment 7 , i.e., $50 \%$ of each source (Tithonia and TSP) combined supplying the required amount of phosphorus, appeared to be practical and feasible for smallholder maize production in the region.

The relationship between agronomic phosphorus use efficiency and grain yield was also positive and linear (Figure 3). At Serbo, $74 \%$ and $99.8 \%$ of the variation in the grain yield, in the first and second years of the experiment, could be explained by the variation in agronomic $\mathrm{P}$ use efficiency with $R^{2}$ values of $74 \%(P<0.001)$ and $99.8 \%$ $(P<0.001)$, respectively. Partial factor productivity was also strongly and positively influenced by the phosphorus input from Tithonia, similar to that of AE (Figure 2).

3.2. Grain Yield and Total Aboveground Biomass. Analysis of variance (ANOVA) indicated that the combined application of Tithonia biomass and phosphorus fertilizer (TSP) significantly affected grain yield of maize $(P<0.05)$. The difference in grain and total aboveground biomass yields of maize between the highest rate (treatment 12) and the intermediate rate (treatment 7) was not statistically significant in the first year although the maximum yields were obtained from the sole application of the highest level of Tithonia biomass (Table 4).

Application of half of the full Tithonia biomass with half of the recommended P from Triple Superphosphate (TSP) resulted in yield increment of $52 \%$ and $22 \%$ over the control and the recommended NP, respectively (Table 4). The relationship between total aboveground biomass and grain yield was strong and positive $\left(R^{2}=0.972, \quad P<0.01\right)$ (Figure 4).

The highest grain yields obtained at Serbo $\left(6305 \mathrm{~kg} \cdot \mathrm{ha}^{-1}\right.$ and $6594 \mathrm{~kg} \cdot \mathrm{ha}^{-1}$ for the first and second year, respectively) were in response to the maximum rate of Tithonia biomass alone (T12: 100\% P from Tithonia biomass), which did not significantly differ from the yield $\left(5818 \mathrm{~kg} \cdot \mathrm{ha}^{-1}\right)$ obtained in response to the combined application of Tithonia biomass and TSP at half of the maximum rates, i.e., treatment number 7 (50\% P from TSP $+50 \%$ P from Tithonia) 
TABLE 3: Grain yield of maize and phosphorus use efficiency as affected by the combined application of Tithonia biomass and phosphorus fertilizer (TSP).

\begin{tabular}{|c|c|c|c|c|c|}
\hline \multicolumn{2}{|c|}{ Phosphorus added $\left(\mathrm{kg} \cdot \mathrm{ha}^{-1}\right)$} & \multirow{2}{*}{$\%$ P from Tithonia } & \multirow{2}{*}{ Grain yield $\left(\mathrm{kg} \cdot \mathrm{ha}^{-1}\right)$} & \multirow{2}{*}{$\mathrm{AE}_{P}$} & \multirow{2}{*}{ PFP-P } \\
\hline From Tithonia & From TSP & & & & \\
\hline 0 & 20.3 & 0 & 3433.7 & 26.3 & 169.1 \\
\hline 6.1 & 14.2 & 30 & 4788.3 & 93.0 & 236.0 \\
\hline 8.3 & 12.0 & 40 & 5121.3 & 109.4 & 252.2 \\
\hline 10.2 & 10.1 & 50 & 5447.3 & 163.0 & 268.3 \\
\hline 12.2 & 8.1 & 60 & 5249.7 & 115.7 & 258.6 \\
\hline 14.2 & 6.1 & 70 & 5761.7 & 140.9 & 283.8 \\
\hline 16.3 & 4.0 & 80 & 5614.7 & 133.7 & 276.5 \\
\hline 18.3 & 2.0 & 90 & 6168.0 & 161.0 & 303.8 \\
\hline 20.3 & 0 & 100 & 6594.3 & 182.0 & 324.8 \\
\hline $\mathrm{LSD}_{0.05}$ & & & 948.1 & 63.9 & 46.7 \\
\hline $\mathrm{SE} \pm$ & & & 316.2 & 21.3 & 15.6 \\
\hline
\end{tabular}

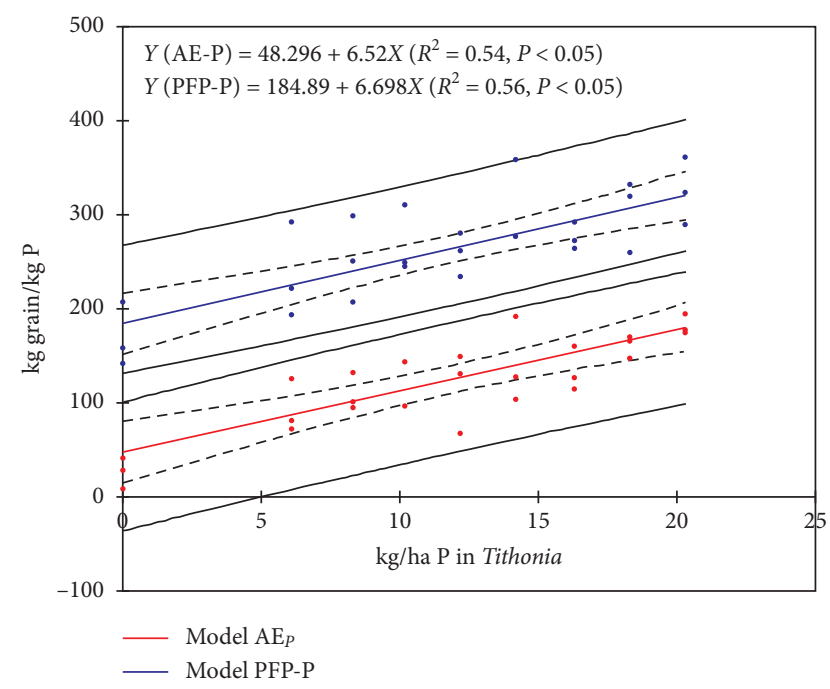

Figure 2: Effect of P supplied to maize through Tithonia biomass on agronomic nutrient use efficiency (AE) and partial factor productivity (PFP) of phosphorus.

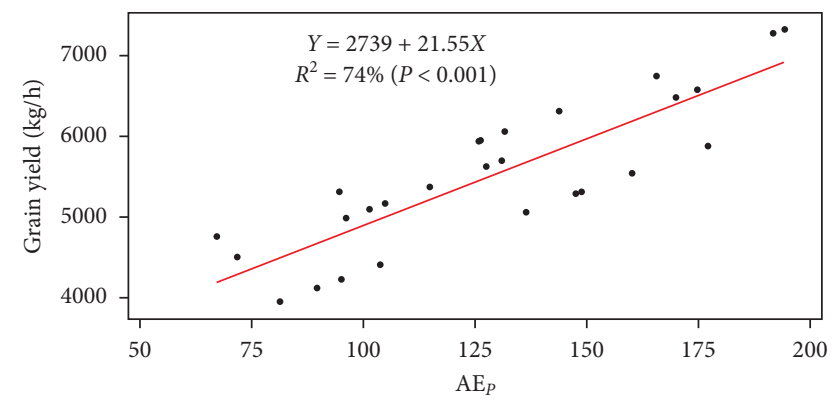

FIGURE 3: Relationship between agronomic phosphorus use efficiency and grain yield.

(Table 4). Considering the huge quantity of Tithonia biomass required to supply the total $P$ requirement of the crop, it will be cheaper and manageable to choose the intermediate treatment level (T7: 50\% P from TSP $+50 \%$ P from Tithonia) as a feasible nutrient management option for the region.
Similarly, application of Tithonia biomass consistently resulted in a higher total aboveground biomass yield of maize compared to all other treatments including the full dose of the recommended inorganic nitrogen and phosphorus fertilizers at all locations (Table 4 and Figure 5). Sole application of Tithonia biomass increased the total aboveground biomass by $52 \%$ and $73 \%$ over the control in the first and second years of the experiment, respectively (Table 4).

Simple regression analysis of the data indicated that the variation observed in the grain yield could be explained by the variation in some of the yield components. The relationship between grain yield and total aboveground biomass was positive and significant $\left(R^{2}=97.2 \%, P<0.05\right)$ (Figures 2 and 3). Similarly, grain yield had a strong positive association with LAI $\left(R^{2}=92.13 \%, P<0.05\right)$.

3.3. Plant Height, Stem Girth, and Internode Length. Yield component parameters such as plant height, stem girth, and internode length were significantly improved $(P<0.05)$ in response to the treatments tested at both locations and years (Table 5). The maximum plant height $(318.33 \mathrm{~cm})$ was recorded in response to the application of Tithonia biomass alone (100\% P from Tithonia) (Table 5). Similarly, stem girth and internode length were positively influenced by the application of Tithonia biomass alone or in combination with the inorganic phosphorus fertilizer (Table 5).

3.4. Leaf Area Index (LAI). In the current study, integrated phosphorus management through Tithonia biomass (transfer) and inorganic phosphorus fertilizer had a significant effect on growth and yield of maize, including leaf area measurements. LAI was significantly affected at both sites where the highest LAI of 2.1 at Melko was recorded for treatment 7 (50\% TSP $+50 \%$ Tithonia biomass) and 1.83 at Serbo at $20 \% \mathrm{TSP}+80 \%$ Tithonia biomass (Table 6 ). The strong positive association observed between leaf area index and grain yield of maize (Figure 6) was also indicative of the significance of the leaf area in growth and yield formation of crops.

Leaf area index (LAI) is among the most important variables in terms of improving crop productivity; it can also 
TABLE 4: Grain and total biomass yield of maize as affected by the combined application of Tithonia biomass and phosphorus fertilizer (TSP) (Serbo, years 1 and 2).

\begin{tabular}{|c|c|c|c|c|c|c|}
\hline \multirow[t]{2}{*}{ Treatment no. } & \multicolumn{2}{|c|}{ Phosphorus added $\left(\mathrm{kg} \cdot \mathrm{ha}^{-1}\right)$} & \multicolumn{2}{|c|}{ Grain yield $\left(\mathrm{kg} \cdot \mathrm{ha}^{-1}\right)$} & \multicolumn{2}{|c|}{$\begin{array}{l}\text { Total aboveground } \\
\text { biomass }\left(\mathrm{kg} \cdot \mathrm{ha}^{-1}\right)\end{array}$} \\
\hline & From Tithonia & From TSP & Year 1 & Year 2 & Year 1 & Year 2 \\
\hline 1 & 0 & 0 & 3810.7 & 2900.3 & 10713.3 & 7300.0 \\
\hline 2 & 0 & 0 & 4585.7 & 3562.0 & 13470.0 & 8500.0 \\
\hline 3 & 0 & 20.3 & 3726.3 & 3433.7 & 11606.7 & 8400.0 \\
\hline 4 & 0 & 20.3 & 4751.0 & 4858.7 & 14540.0 & 10133.3 \\
\hline 5 & 6.1 & 14.2 & 5579.7 & 4788.3 & 15223.3 & 10266.7 \\
\hline 6 & 8.3 & 12.0 & 5104.3 & 5121.3 & 14790.0 & 10266.7 \\
\hline 7 & 10.2 & 10.1 & 5818.3 & 5447.3 & 15216.7 & 10900.0 \\
\hline 8 & 12.2 & 8.1 & 5892.3 & 5249.7 & 15373.3 & 10500.0 \\
\hline 9 & 14.2 & 6.1 & 6136.7 & 5761.7 & 16303.3 & 11600.0 \\
\hline 10 & 16.3 & 4.0 & 5782.0 & 5614.7 & 16003.3 & 10666.7 \\
\hline 11 & 18.3 & 2.0 & 5789.7 & 6168.0 & 15703.3 & 12433.3 \\
\hline 12 & 20.3 & 0 & 6305.0 & 6594.3 & 16260.0 & 12600.0 \\
\hline $\mathrm{LSD}_{0.05}$ & & & 729.4 & 957.2 & 1889 & 1650 \\
\hline CV\% & & & 8.17 & 11.40 & 7.64 & 9.46 \\
\hline
\end{tabular}

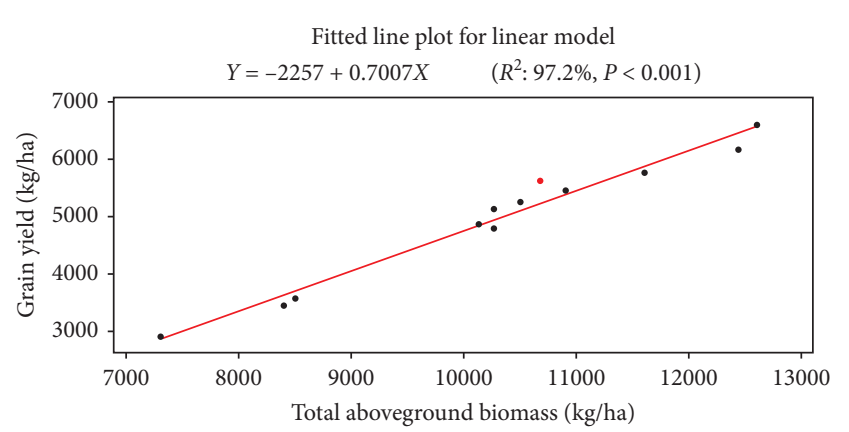

FIGURE 4: Relationship between grain yield and total aboveground biomass of maize.

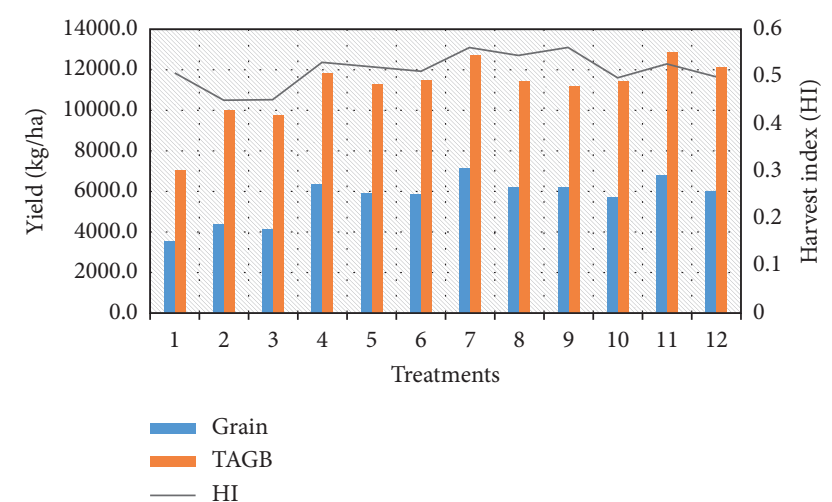

FIgUre 5: Effect of combined TSP and Tithonia biomass application on grain yield, total aboveground biomass, and HI of maize. Note: $1=$ control; $2=\mathrm{N}$ (full dose); $3=\mathrm{P}$ (full dose); $4=\mathrm{NP}$ (recommended rate); $5=70 \% \mathrm{P}$ (TSP) $+30 \% \mathrm{P}$ (Tithonia); $6=60 \% \mathrm{P}$ (TSP) $+40 \% \mathrm{P}$ (Tithonia); $7=50 \% \mathrm{P}$ (TSP) $+50 \% \mathrm{P}$ (Tithonia); $8=40 \% \mathrm{P}(\mathrm{TSP})+60 \% \mathrm{P}$ (Tithonia); $9=30 \% \mathrm{P}(\mathrm{TSP})+70 \% \mathrm{P}$ (Tithonia); $10=20 \%$ P (TSP) $+80 \%$ P (Tithonia); $11=10 \% \quad \mathrm{P}$ (TSP) $+90 \%$ P (Tithonia); $12=$ Tithonia alone (100\% P).

be widely modified by manipulating agronomic practices [24]. Most agronomic practices including nutrient management are often aimed at achieving higher LAI for maximizing interception of radiation which in turn maximizes the total dry matter production and grain yield.

Data on leaf area measurements collected at Melko could be seen as the best scenario to explain why we need to integrate organic and inorganic sources of nutrients rather than using either source alone. The maximum leaf area and LAI were recorded in response to the $7^{\text {th }}$ treatment where phosphorus was supplied from the combined application of $50 \%$ of Tithonia biomass and 50\% of TSP (Table 6); these values also corresponded with the maximum grain and biomass yield values (Figure 6).

\section{Discussion}

The improvement in phosphorus use efficiency following the combined application of Tithonia biomass and fertilizer TSP reported here appears consistent with previous reports. Considering the role of organic residues in reducing soil $\mathrm{P}$ adsorption capacity [15], increasing soil pH [16], and increasing soil biological activity [17], improvement in efficiency of applied inorganic phosphorus should normally be expected when integrated with organic sources of phosphorus such as Tithonia biomass. Nziguheba et al. [8] presented data showing similar or larger effects on available $\mathrm{P}$ pools as a result of combining Tithonia diversifolia (Hemsley A. Gray) and TSP than the sources applied alone.

The results reported in this study are therefore in line with the stated goal of integrated nutrient management (INM), which is to integrate the use of all natural and manmade sources of plant nutrients, so that crop productivity increases in an efficient and environmentally benign manner, without sacrificing soil productivity of future generations [18].

The result generally shows the positive role of Tithonia biomass as a source of phosphorus for maize production on acidic nitosols of southwestern Ethiopia and supports results of a previous study by Solomon and Jafer [25] in which Tithonia biomass was successfully used as a viable input for integrated soil fertility management strategy for maize on 
TABLE 5: Growth characteristics of maize as affected by the combined application of Tithonia biomass and phosphorus fertilizer (TSP).

\begin{tabular}{|c|c|c|c|c|c|c|c|c|}
\hline \multirow{2}{*}{$\begin{array}{l}\text { Treatment } \\
\text { no. }\end{array}$} & \multicolumn{2}{|c|}{$\begin{array}{l}\text { Phosphorus added } \\
\left(\mathrm{kg} \cdot \mathrm{ha}^{-1}\right)\end{array}$} & \multicolumn{3}{|c|}{ Location: Serbo } & \multicolumn{3}{|c|}{ Location: Melko } \\
\hline & $\begin{array}{c}\text { From } \\
\text { Tithonia }\end{array}$ & $\begin{array}{c}\text { From } \\
\text { TSP }\end{array}$ & Plant height $(\mathrm{cm})$ & Internode length $(\mathrm{cm})$ & Stem girth $(\mathrm{cm})$ & $\begin{array}{c}\text { Plant } \\
\text { height }(\mathrm{cm})\end{array}$ & $\begin{array}{l}\text { Internode } \\
\text { length }(\mathrm{cm})\end{array}$ & $\begin{array}{c}\text { Stem } \\
\text { girth }(\mathrm{cm})\end{array}$ \\
\hline 1 & 0 & 0 & 284.67 & 17.5 & 8.1 & 254.0 & 17.2 & 7.7 \\
\hline 2 & 0 & 0 & 275.67 & 17.1 & 7.1 & 264.3 & 18.3 & 8.0 \\
\hline 3 & 0 & 20.3 & 296.33 & 16.2 & 8.5 & 276.0 & 16.9 & 8.4 \\
\hline 4 & 0 & 20.3 & 306.67 & 17.3 & 8.2 & 305.7 & 16.4 & 8.6 \\
\hline 5 & 6.1 & 14.2 & 304.67 & 17.0 & 8.8 & 319.0 & 18.0 & 8.6 \\
\hline 6 & 8.3 & 12.0 & 304.33 & 17.4 & 8.7 & 303.0 & 17.7 & 9.0 \\
\hline 7 & 10.2 & 10.1 & 305.67 & 16.3 & 8.5 & 317.7 & 18.2 & 9.4 \\
\hline 8 & 12.2 & 8.1 & 300.33 & 18.4 & 8.2 & 300.3 & 17.1 & 9.1 \\
\hline 9 & 14.2 & 6.1 & 311.33 & 18.0 & 8.7 & 294.7 & 17.1 & 9.2 \\
\hline 10 & 16.3 & 4.0 & 304.67 & 17.4 & 8.1 & 307.3 & 18.3 & 8.9 \\
\hline 11 & 18.3 & 2.0 & 316.67 & 17.7 & 8.7 & 306.3 & 18.2 & 9.4 \\
\hline 12 & 20.3 & 0 & 318.33 & 18.2 & 8.4 & 290.3 & 15.1 & 8.7 \\
\hline $\mathrm{LSD}_{0.05}$ & & & 13.76 & 1.119 & 0.788 & 33.23 & ns & 1.06 \\
\hline CV\% & & & 2.69 & 3.80 & 5.60 & 13.73 & 11.34 & 7.14 \\
\hline
\end{tabular}

TABLE 6: Leaf area measurements of maize as affected by the combined application of Tithonia biomass and phosphorus fertilizer (TSP).

\begin{tabular}{|c|c|c|c|c|c|}
\hline \multirow{3}{*}{ Treatment no. } & \multicolumn{3}{|c|}{ Amount of $\mathrm{P}$ added $\left(\mathrm{kg} \cdot \mathrm{ha}^{-1}\right)$} & \multirow{2}{*}{\multicolumn{2}{|c|}{$\begin{array}{c}\text { LAI } \\
\text { Location }\end{array}$}} \\
\hline & \multirow{2}{*}{ From Tithonia } & \multirow{2}{*}{ From TSP } & \multirow{2}{*}{$\%$ P from Tithonia } & & \\
\hline & & & & Serbo & Melko \\
\hline 1 & 0 & 0 & 0 & 1.30 & 1.30 \\
\hline 2 & 0 & 0 & 0 & 1.30 & 1.57 \\
\hline 3 & 0 & 20.3 & 0 & 1.30 & 1.50 \\
\hline 4 & 0 & 20.3 & 0 & 1.30 & 1.90 \\
\hline 5 & 6.1 & 14.2 & 30 & 1.63 & 1.70 \\
\hline 6 & 8.3 & 12.0 & 40 & 1.67 & 1.40 \\
\hline 7 & 10.2 & 10.1 & 50 & 1.60 & 2.10 \\
\hline 8 & 12.2 & 8.1 & 60 & 1.33 & 1.80 \\
\hline 9 & 14.2 & 6.1 & 70 & 1.67 & 1.87 \\
\hline 10 & 16.3 & 4.0 & 80 & 1.83 & 1.87 \\
\hline 11 & 18.3 & 2.0 & 90 & 1.53 & 1.93 \\
\hline 12 & 20.3 & 0 & 100 & 1.67 & 1.60 \\
\hline $\mathrm{LSD}_{0.05}$ & & & & 0.142 & 0.20 \\
\hline CV\% & & & & 5.39 & 6.87 \\
\hline
\end{tabular}

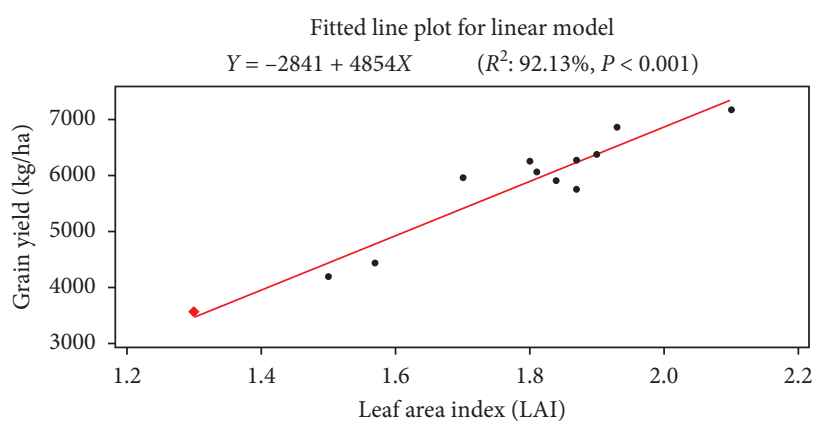

FIGURE 6: Relationship between grain yield and LAI.

acidic nitosols of the region. The relatively high content of nutrients in its biomass [1] and the ease of decomposition and subsequent release of nutrients retained in the biomass upon incorporation in to the soil [3] could be some of the reasons behind the positive roles of Tithonia biomass application.
Application of the full recommended phosphorus rate $\left(20.3 \mathrm{~kg} \cdot \mathrm{ha}^{-1}\right)$ from Tithonia biomass alone may supply up to $203 \mathrm{~kg} \cdot \mathrm{ha}^{-1} \mathrm{~N}$ which amounts to around $300 \%$ of the recommended nitrogen rate for the area. Applying half of the recommended $\mathrm{P}$ rate (i.e., $10.2 \mathrm{~kg} \cdot \mathrm{ha}^{-1}$ ) from Tithonia biomass would therefore add about $102 \mathrm{~kg} \cdot \mathrm{ha}^{-1}$ nitrogen, which corresponds to around $167 \%$ of the recommended nitrogen rate for the area. This strongly suggests that $\mathrm{Ti}$ thonia biomass may provide sufficient level of nitrogen to the growing maize crop as long as the amount of Tithonia biomass added to the soil (through biomass transfer) supplies half of the recommended phosphorus (i.e., $10.2 \mathrm{~kg} \cdot \mathrm{ha}^{-1}$ ), in which case the remaining half can be supplied from the inorganic phosphorus fertilizer.

Therefore, the relatively high amount of nitrogen and phosphorus in Tithonia biomass, around 3\% and $0.3 \%$, respectively, might be the main reasons for the consistently better performance of Tithonia biomass supplied maize plots 
in all sites of the study area. The faster release of $\mathrm{N}$ and $\mathrm{P}$ from the leaf biomass [3] may have additionally contributed to better nutrient supply and corresponding increase in grain yield. The nutrients in Tithonia biomass are rapidly released in plant-available forms during decomposition $[3,11]$. Tithonia residues have also been shown to reduce $\mathrm{P}$ sorption sites, $\mathrm{P}$ metal complexes, $\mathrm{Al}$ toxicity, and ameliorate soil aggregation [26].

Several studies on the use of nontraditional organic materials such as weeds including Tithonia for soil fertility management have repeatedly shown high potential for improving nutrient status of soils and subsequent crop yields in many parts of Africa [5, 27-29]. Chukwuka and Omotayo [26] observed improved the micronutrient status of soils amended with Tithonia biomass. Similarly, Gachengo et al. [3] reported relatively high concentration of nutrients in Tithonia green biomass in addition to $\mathrm{N}, \mathrm{P}$, and $\mathrm{K}$.

Reports of maize yield improvement due to integrated use of organic and inorganic nutrient sources are widely found in the literature $[25,30-32]$ although the types and proportion of organic materials used as nutrient sources vary depending on availability of the resources per se and locations where these resources are applied, hence requiring specific studies at each locality or site taking unique local circumstances in to consideration.

Leaf area characteristics of crops are crucial in yield formation and productivity per unit area [33]. The increased LAI of maize with the application of Tithonia biomass and TSP (Table 5 and Figure 5) could be attributed to better growth and development of leaves with corresponding improvements in net $\mathrm{CO}_{2}$ assimilation ultimately leading to better grain and biomass yields. Improved availability and uptake of nutrients including enhanced chlorophyll content and leaf $\mathrm{N}$ concentration boosted photosynthetic activities and enhanced maize yield [34].

Therefore, the significant improvement in grain yield and agronomic phosphorus use efficiency in response to the application of the phosphorus fertilizer in combination with Tithonia biomass indicated the strong potential of Tithonia biomass as a source of phosphorus highlighting its role in integrated soil fertility management for smallholder maize producers in southwestern Ethiopia and other places with similar environments.

\section{Conclusion}

The effect of phosphorus, applied through TSP and/or Tithonia biomass, on the grain yield of maize was significant and similar across locations, highlighting the potential role of Tithonia biomass as a cheap source of plant nutrients through the biomass transfer.

The use of Tithonia biomass, either alone or in combination with the phosphorus fertilizer, has significantly improved agronomic phosphorus use efficiency, grain yield, and yield components of maize.

Phosphorus is one of the most important plant nutrients but largely deficient in soils of southwestern Ethiopia. Hence, a sound integrated nutrient management strategy, one that includes Tithonia biomass and inorganic phosphorus fertilizers, would adequately address the limitation imposed by low soil $\mathrm{N}$ and $\mathrm{P}$ levels towards improving crop productivity in the region.

The nitrogen requirement of the crop could also be satisfied from the Tithonia biomass, relieving farmers of the extra financial burden for the purchase of inorganic nitrogen fertilizers such as urea.

Though the total amount of $\mathrm{P}$ added from both sources remained the same (i.e., $20.3 \mathrm{~kg} / \mathrm{ha}$ ), yield response and nutrient use efficiency parameters were positively associated more with phosphorus from Tithonia than that of TSP. The observed association between these parameters (yield and nutrient use efficiency) and $\mathrm{P}$ input from Tithonia biomass was linear and positive despite the reduction in the $\mathrm{P}$ input from TSP with increasing levels of Tithonia biomass.

Finally, as the focus of this study was purely on the agronomic potentials of Tithonia biomass for smallholder maize production, the multiplication and utilization of Tithonia for nutrient management purposes as stipulated in the study should be carefully managed; and activities for wider dissemination of Tithonia in the region need to assess results of economic evaluation and analysis of empirical data involving weed science studies to address some of the concerns voiced regarding the weedy nature of the plant.

\section{Data Availability}

The data used to support the findings of this study are available from the corresponding author upon request.

\section{Conflicts of Interest}

The author declares that there are no conflicts of interest regarding the publication of this paper.

\section{References}

[1] C. A. Palm, R. J. K. Myers, and S. M. Nandwa, "Combined use of organic and inorganic nutrient sources for soil fertility maintenance and replenishment," in Replenishing Soil Fertility in Africa, R. J. Buresh et al., Eds, pp. 193-217, ASA and SSSA, Madison, WI, USA, 1997.

[2] T. S. George, P. J. Gregory, J. S. Robinson et al., "Tithonia diversifolia: variations in leaf nutrient concentration and implications for biomass transfer," Agroforestry Systems, vol. 52, pp. 199-205, 2001.

[3] C. N. Gachengo, C. A. Palm, B. Jama, and C. Otieno, "Combined use of trees, shrubs and inorganic sources for soil fertility improvement," Agroforestry Systems, vol. 44, pp. 2136, 1999.

[4] ICRAF, Annual Report for 1996, International Center for Research in Agro Forestry, Nairobi, Kenya, 1997.

[5] B. Jama, C. A. Palm, R. J. Buresh et al., "Tithonia diversifolia as a green manure for soil fertility improvement in western Kenya: a review," Agroforestry Systems, vol. 49, no. 2, pp. 201-221, 2000.

[6] O. S. Olabode, S. Ogunyemi, W. B. Akambi, G. O. Adesina, and P. A. Babajide, "Evaluation of Tithonia diversifolia (Hemsl. A. Grey) for soil improvement," World Journal of Agricultural Sciences, vol. 3, no. 4, pp. 503-507, 2007. 
[7] J. Achieng, G. Ouma, G. Odhiambo, and F. Muyekho, "Effect of Tithonia diversifolia (Hemsley) and inorganic fertilizers on maize yield on alfisols and ultisols of Western Kenya," Agriculture and Biology Journal of North America, vol. 1, no. 5, pp. 740-747, 2010.

[8] G. Nziguheba, C. A. Palm, R. J. Buresh, and P. C. Smithson, "Soil phosphorus fractions and adsorption as affected by organic and inorganic sources," Plant and Soil, vol. 198, no. 2, pp. 159-168, 1998.

[9] G. Blair and O. Boland, "The release of phosphorus from plant material added to soil," Soil Research, vol. 16, no. 1, pp. 101-111, 1978.

[10] B. Vanlauwe, C. A. Palm, H. K. Murwira, R. Merckx, and R. Delve, "Organic resource management in Sub-Saharan Africa: validation of residue quality-driven decision support system," in Proceedings of the 17th World Congress of Soil Science (WCSS), pp. 14-21, Bangkok, Thailand, August 2002.

[11] G. Nziguheba, R. Merckx, C.A. Palm, and M. Rao, "Organic residues affect phosphorus availability and maize yields in a Nitisol of western Kenya," Biology and Fertility of Soils, vol. 32, pp. 328-339, 2000.

[12] R. Ganunga, Y. Olusegun, and D. T. John, "Nitrogen and phosphorus uptake from Tithonia diversifolia (Hemsley) A Gray and inorganic fertilizer and their effect on maize yield (Zea mays L.) in Malawi. In maize production technology for the future: challenges and opportunities," in Proceedings of the Sixth Eastern and Southern Africa Regional Maize Conference, Addis Ababa, Ethiopia, September 1998.

[13] O. Jiri and S. R. Waddington, "Leaf prunings from two species of tithonia raise maize grain yield in Zimbabwe, but take a lot of labor! Newsletter of Soil Fert Net, Harare, Zimbabwe," Target, vol. 16, pp. 4-5, 1998.

[14] C. A. Palm, "Contribution of agroforestry trees to nutrient requirements of intercropped plants," Agroforestry: Science, Policy and Practice, vol. 30, pp. 105-124, 1995.

[15] G. W. Easterwood and J. B. Sartain, "Clover residue effectiveness in reducing orthophosphate sorption on ferric hydroxide coated soil," Soil Science Society of America Journal, vol. 54, no. 5, pp. 1345-1350, 1990.

[16] R. M. Kretzschmar, H. Hafner, A. Bationo, and H. Marschner, "Long- and short-term effects of crop residues on aluminum toxicity, phosphorus availability and growth of pearl millet in an acid sandy soil," Plant and Soil, vol. 136, no. 2, pp. 215-223, 1991.

[17] J. L. Smith, R. I. Papendick, D. F. Bezdicek, and J. M. Lynch, "Soil organic matter dynamics and crop residue management," in Soil Microbial Ecology: Applications in Agricultural and Environmental Management, M. F. Blaine Jr., Ed., pp. 65-94, Marcel Decker, New York, NY, USA, 1993.

[18] FAO, Plant Nutrition for Food Security, a Guide for Integrated Nutrient Management, vol. 16, FAO Fertilizer and Plant Nutrition Bulletin, Rome, Italy, 2006.

[19] G. Nziguheba, R. Merckx, C. A. Palm, and M. R. Rao, "Organic residues affect phosphorus availability and maize yields in a nitisol of Western Kenya," Biology and Fertility of Soils, vol. 32, no. 4, pp. 328-339, 2000.

[20] O. M. Abukutsa and J. C. Onyango, "Influence of organic and inorganic sources of fertilizer on growth and leaf yield of kale," Journal of Agriculture, Science and Technology, vol. 4, no. 1, 2002.

[21] M. O. Liasu, A. O. Ogundare, and M. O. Ologunde, "Effect of soil supplementation with fortified tithonia mulch and directly applied inorganic fertilizer on growth and development of potted okra plants," American Eurasian Journal of Sustainable Agriculture, vol. 2, no. 3, pp. 264-270, 2008.

[22] T. Fairhurst, Handbook for Integrated Soil Fertility Management, Africa Soil Health Consortium, Nairobi, Kenya, 2012.

[23] XLSTAT 2018, Adinsoft Inc., Long Island City, NY, USA, 2018.

[24] S. A. Anjum, U. Ashraf, A. Zohaib et al., "Growth and developmental responses of crop plants under drought stress: a review," Zemdirbyste-Agriculture, vol. 104, no. 3, pp. 267-276, 2017.

[25] E. Solomon and D. Jafar, "Yield response of maize to integrated soil fertility management on acidic nitosol of Southwestern Ethiopia," Journal of Agronomy, vol. 14, no. 3, pp. 152-157, 2015.

[26] P. T. Cong, Improving phosphorus availability in selected soils from the uplands of the south of Vietnam by residue management. A case study: Tithonia diversifolia, Ph.D. Thesis, Katholiek Universiteit Leuven, Leuven, Belgium, 2000.

[27] K. S. Chukwuka and O. E. Omotayo, "Effects of tithonia green manure and water hyacinth compost application on nutrient depleted soil in South-Western Nigeria," International Journal of Soil Science, vol. 3, no. 2, pp. 69-74, 2008.

[28] G. Nziguheba, R. Merckx, C. A. Palm, and P. Mutuo, "Combined use of Tithonia diversifolia and inorganic fertilizers for improving maize production in a phosphorus deficient soil in Western Kenya," Biology and Fertility of Soils, vol. 23, pp. 330-343, 2002.

[29] D. Sonke, "Tithonia weed a potential green manure crop," ECHO Development Notes, vol. 57, pp. 5-6, 1997.

[30] B. J. Haghighi, Z. Yarmahmodi, and O. Alizadeh, "Evaluation the effects of biological fertilizer on physiological characteristic and yield and its components of corn (Zea mays L.) under drought stress," American Journal of Agricultural and Biological Sciences, vol. 5, no. 2, pp. 189-193, 2010.

[31] D. T. Shui, J. Yun, H. Shaowen, L. S. Tian, and H. E. Ping, "Effect of long-term application of $\mathrm{K}$ fertilizer and wheat straw to soil on crop yield and soil $\mathrm{K}$ under different planting systems," Agricultural Sciences in China, vol. 6, no. 2, pp. 200-207, 2007.

[32] S. I. Zamir, M. Asif, I. Haq, U. Ashraf, S. Hussain, and M. K. Khan, "Maize phenology, yield, and its quality is affected by organic mulches and various irrigation regimes," International Journal of Modern Agriculture, vol. 3, no. 2, pp. 56-59, 2014.

[33] K. Mengel and E. A. Kirkby, Principles of Plant Nutrition, Kluwer Academic Publishers, Dordrecht, The Netherlands, 5th edition, 2001.

[34] B. J. Amujoyegbe, J. T. Opabode, and A. Olayinka, "Effect of organic and inorganic fertilizer on yield and chlorophyll content of maize (Zea mays L.) and sorghum Sorghum bicolour (L.) Moench," African Journal of Biotechnology, vol. 6, no. 16, pp. 1869-1873, 2007. 


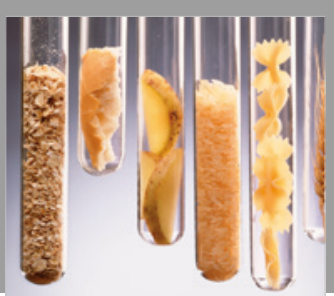

International Journal of Food Science

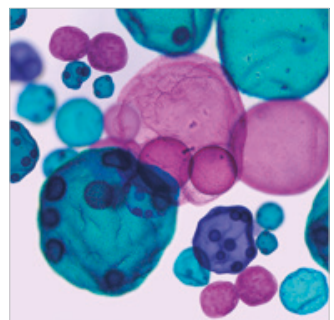

International Journal of Microbiology
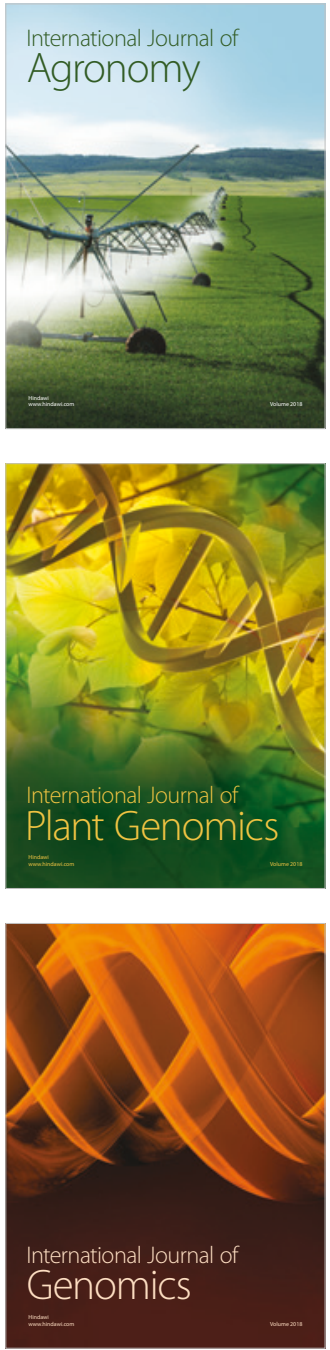

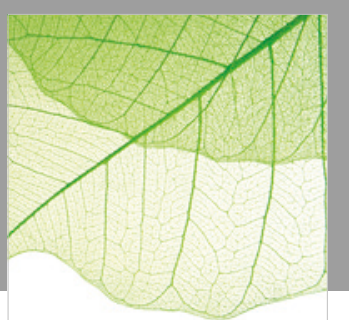

Journal of Botany
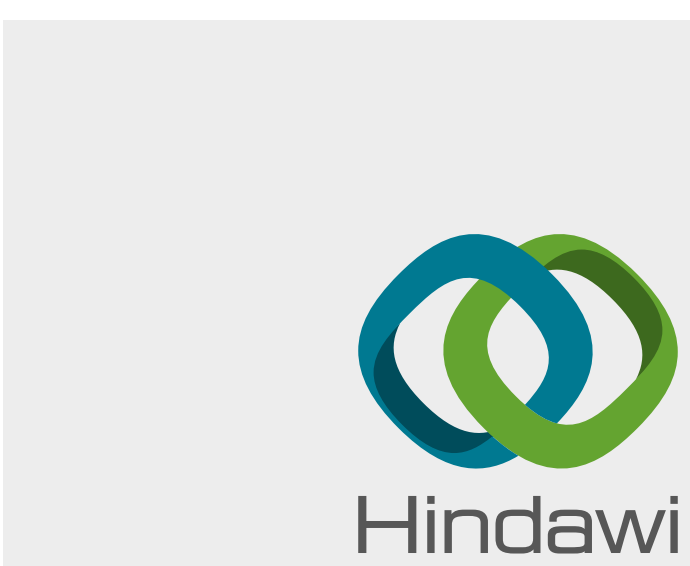

Submit your manuscripts at

www.hindawi.com
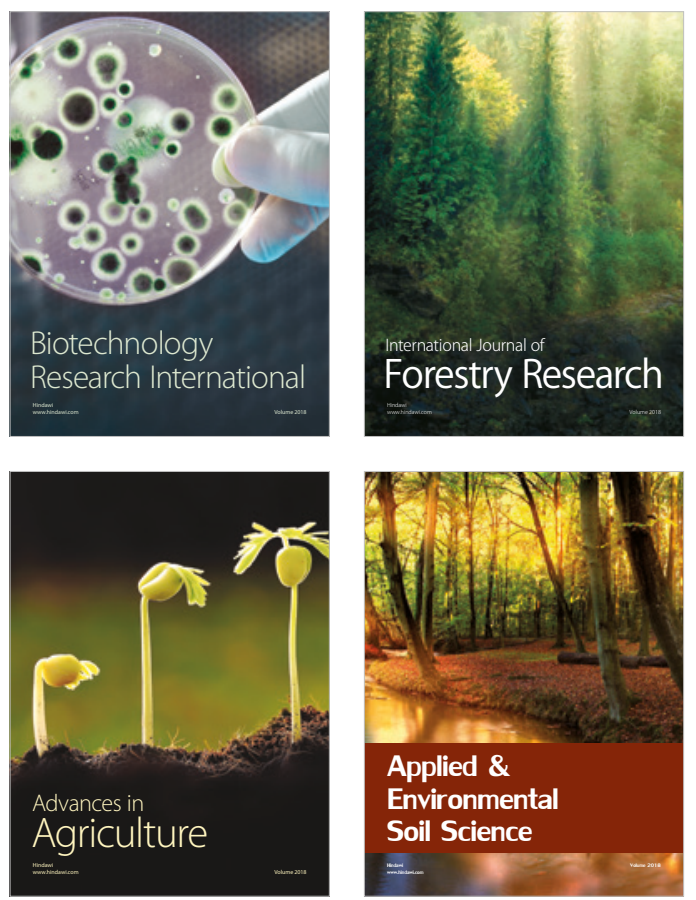

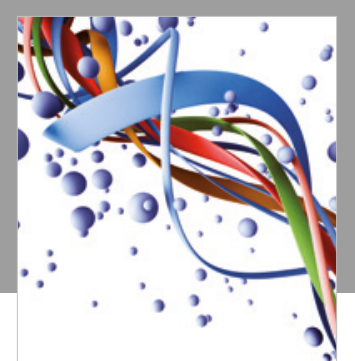

Scientifica

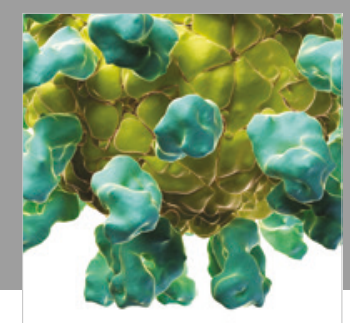

Veterinary Medicine International

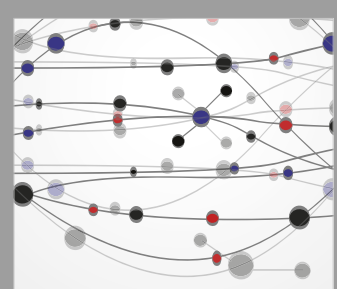

The Scientific World Journal
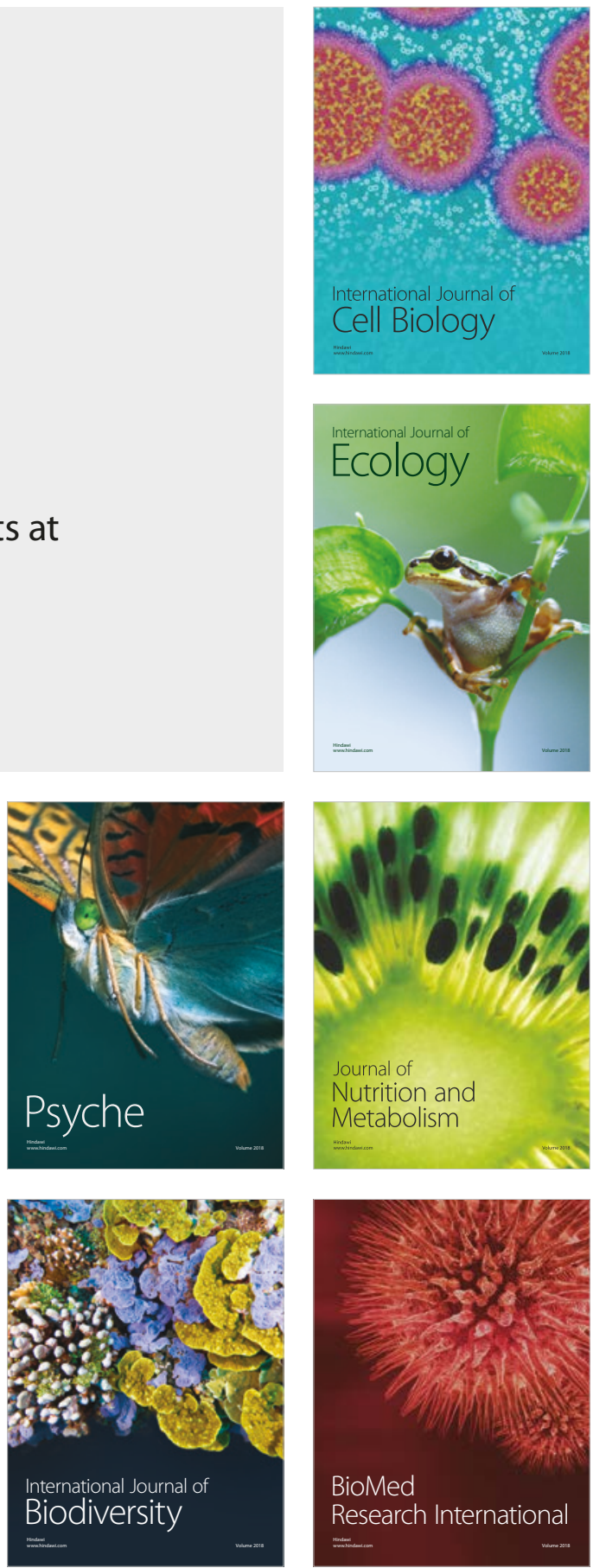